УДК 81-22

\title{
СХОДСТВА И РАЗЛИЧИЯ АНГЛИЙСКОГО И НЕМЕЦКОГО ЯЗЫКОВ
}

\author{
Путейнис Анна Юрисовна \\ Научные руководители: Милокумова Светлана Юрьевна \\ Постникова Татьяна Осиповна \\ учителя английского и немецкого языков \\ МБОУ СОШ №18 \\ г.Химки, МО
}

Аннотация: В статье даётся сравнение двух иностранных языков (английского и немецкого), а именно их сходства и различия. Оба языка, являются родственными по своему происхождению, особое внимание уделено проведению аналогии лексики.

Ключевые слова: английский, немецкий языки, схожесть, различия, современное общество, лексика

\section{SIMILARITIES AND DIFFERENCES BETWEEN ENGLISH AND GERMAN LANGUAGES}

\section{Scientific advisers: Milokumova Svetlana Yuryevna Postnikova Tatyana Osipovna}

В древности говорили так: сколько языков ты знаешь, столько раз ты человек. В современном мире интерес к иностранным языкам достаточно велик. Основания для изучения могут быть как личными, так и профессиональными. В наши дни люди достаточно много путешествуют, и для этого тоже очень важно знать иностранные языки. Марк Твен сказал: « Никогда не будет голоден тот, кто знает язык страны».

Изучение иностранного языка в современном мире - это один из самых важных составляющих моментов современного, успешного человека. Знание хотя бы одного иностранного языка расширяет кругозор, позволяет узнать культуру и обычаи другого народа. 


\section{ВСЕРОССИЙСКИЙ ИССЛЕДОВАТЕЛЬСКИЙ ФОРУМ

Сегодня миллионы людей во всем мире изучают иностранные языки. Это позволяет путешествовать по всему миру и везде общаться с людьми, узнавать все новости первыми, так как можно смотреть международные телевизионные передачи и слушать репортажи по радио на иностранном языке.

Мы изучаем английский язык со второго класса, нам он очень интересен, a c этого года мы начали изучать немецкий язык, как второй иностранный язык. Были удивлены, как похожи эти два языка. Нам захотелось, больше узнать и поэтому мы выбрали тему «сходства и различия английского и немецкого языков.

Имеющийся языковой опыт позволяет нам выдвинуть следующую гипотезу исследования: немецкий и английский язык являются родственными языками, анализ сходств и отличий между этими языками позволит ускорить и облегчить процесс изучения этих языков.

Таким образом, тема данного исследования актуальна, так как изучение иностранных языков - это процесс получения знания, которое жизненно необходимо в современном обществе.

Цель работы - доказать, что изучение второго языка дается легче, чем первого. Собрать факты, свидетельствующие о том, что европейские языки имеют не только различия, но и характерные сходства, которые облегчают их изучение. Определить актуальность немецкого языка в современном мире и российском обществе.

Предмет исследования - английский и немецкий языки. Мы поставили перед собой следующие задачи:

1) Проанализировать лексику в обоих языках.

2) Найти слова, имеющие сходства.

3) Найти причины, объясняющие сходства и различия языков.

4) Изучить материалы о месте немецкого языка в современном мире.

Методы исследования:

1) наблюдательный метод;

2) сравнительный метод.

Объект исследования: учебник для 8 класса по английскому и учебник 5 кл. по немецкому языку как второй иностранный язык (лексика английского и немецкого языков), словари.

По популярности у россиян немецкий язык сегодня занимает прочное второе место после английского. Хотя интерес к языку Шиллера и Гёте в России не всегда был одинаков. Однако постепенно число желающих 


\section{ВСЕРОССИЙСКИЙ ИССЛЕДОВАТЕЛЬСКИЙ ФОРУМ

овладеть немецким языком начало расти. Эксперты отчасти связывают это с приходом к власти владеющего немецким языком Владимира Путина. Своё влияние оказывает мода на европейский стиль жизни, в котором знание нескольких иностранных языков является нормой, и простой человеческий интерес к немецкой культуре.

Многие народы, племена внесли свой вклад в становление, как английского, так и немецкого языков. В настоящее время языки отражают все изменения, которым они подвергались на протяжении всей истории их становления.

Мы выяснили, что немецкий и английские языки относятся к одной языковой семье - индоевропейской и к одной группе - германской, и к одной подгруппе - западно-германской. Мы обнаружили, что народы Англии и Германии имеют общее происхождение, их предки - племена древних германцев.

Таким образом, сходство немецкого и английского языков объясняется общим происхождением этих языков.

Немцы и англичане когда - то были единым народом, которые жили на территории Европы. Предками англичан были племена англов, саксов и ютов, а предками немцев были племена алеманов, баварцев и лангобардов.

В 4-7 веках в эпоху Великого переселения народов, германские племена - англы, саксы и юты (предки англичан) переселились в Британию, где в то время жили кельты. Немецкие племена захватили земли кельтов, и немецкий язык обогатился заимствованиями из кельтского и латинского языков (до кельтов в Британии жили римляне). Но ядро немецкого языка не изменилось.

Из этого следует, что основа английского языка осталась германской, но он включает в себя огромное количество французских, латинских, кельтских и скандинавских заимствований по причине переселения народов и захвата территорий. Основой же немецкого языка являются наречия древнегерманских племён.

За основу анализа мы взяли лексику английского и немецкого языков. Мы рассмотрели лексику в комплексе. Мы изучали написание слов и их значения и сходства в произношении.

Используя, сравнительный метод исследования мы выявили слова, которые имеют сходства в написании и совпадают по значению. Вот некоторые из них (табл.1): 
Таблица 1

\section{Слова, которые совпадают по написанию \\ и по значению в обоих языках}

\begin{tabular}{|c|c|c|}
\hline Немецкое слово & Значение & Английское слово \\
\hline Der Winter & зима & winter \\
\hline Hallo & привет & have \\
\hline haben & иметь & family \\
\hline Die Familie & семья & son \\
\hline Der Sohn & сын & drink \\
\hline Die Sonne & солнце & book \\
\hline Trinken & пить & name \\
\hline Das Buch & книга & hand \\
\hline Die Name & имя & land \\
\hline Die Hand & рука & wind \\
\hline Das Land & Мир, земля & man \\
\hline Der Wind & ветер & nature \\
\hline Der Mann & Человек,мужчина & Is (be) \\
\hline Die Natur & природа & \\
\hline Ist(sein) & Глагол связка от & гл.быть \\
\hline
\end{tabular}

Мы обнаружили, что в обоих языках есть слова схожие по написанию, но отличающиеся по значению (табл.2).

Таблица 2

\section{Слова, которые внешне похожи в обоих языках, но имеют разные значения}

\begin{tabular}{|l|l|l|l|}
\hline \multirow{2}{*}{ Немецкое слово } & \multirow{2}{*}{ Английское слово } & Значение \\
\cline { 3 - 4 } & & Немецкий & Английский \\
\hline Brav & Brave & Хороший & Храбрый \\
\hline Das Gift & gift & Яд & подарок \\
\hline schmal & Small & узкий & маленький \\
\hline streng & Strong & строгий & сильный \\
\hline
\end{tabular}

Мы узнали, сходство немецкого и английского языков объясняется общим происхождением, отношением обоих языков к германской группе и западно-германской подгруппе языкового древа. 
В ходе исследования нашла подтверждение гипотеза о том, что немецкий и английский язык являются родственными языками, анализ сходств и отличий между этими языками позволит ускорить и облегчить процесс изучения этих языков.

Практическое применение данного исследования заключается в том, что оно может помочь всем желающим в изучении второго иностранного языка, а также будет интересно педагогам, преподающим английский или немецкий язык как второй иностранный.

\section{Список литературы}

1. В.В. Бабайцева, русский язык, 5-9 класс, М. Просвещение, 2019

2. М.И. Кириллова в защиту немецкого языка//ИЯ в школе. - 2016. №10. - c.17-20.

3. А.Л.Зеленецкий, Сравнительная типология основных европейский языков, М.Академия, 2004. 